\title{
PELAKSANAAN PERATURAN DAERAH PROVINSI BALI NO 5 TAHUN 2008 TENTANG PRAMUWISATA DI KABUPATEN BADUNG
}

\author{
Oleh : \\ Ni Made Anggia Paramesthi Fajar ${ }^{1}$
}

\begin{abstract}
Tour guide has an important role toward the tourism business in Bali, they take care the guests since they arrive until they depart from Bali. Therefore a tour guide should be able to give the best quality of service and also improve it if to provide better service in the future. In order to achieve the best quality of service, the government should create a rule which regulate how a tour guide can be a profession in order to provide a better quality of service to the guests who visit Bali. Bali Regional Rule no 5 year 2008 about Tour Guides is a kind of regulation established by Bali Government as a foundation for a Tour Guide in doing their profession. However, in fact there are so many irrelevant services given by a Tour Guide and it was not based on the regulation and it caused the problems in this thesis. Are there any factors that generate a specific license for a tour guide based on Bali Regional Rule no 5 year 2008 about Tour Guides could not be released? How is the application of punishment ofthose tour guides who did not obey the regulation based on Bali Regional Rule no 5 year 2008 about Tour Guides?

This research used empiric approach which means that we are doing an approach by solving the problem that we face during the research. In relation with the regulations and law and also the law theories which relevant applied in this research e.g. theory of obeying the law, theory of authority and theory of product quality. In order to show the government's authority to apply the law and how the regulation is able to guarantee the law and also to ensure that the government regulation can guarantee the tour guide quality to provide the best quality of services.
\end{abstract}

\section{Keywords: tour guide, cultural tourism, Tourism Perda application, law punishment}

\section{PENDAHULUAN}

\subsection{Latar Belakang Masalah}

Pariwisata didaerah Bali merupakan sektor paling maju dan berkembang, dan masih tetap berpeluang ke depannya untuk dikembangkan menjadi lebih modern lagi. Daerah Bali memiliki obyek wisata yang beragam, baik wisata alam, wisata sejarah

Mahasiswa Program Studi Magister (S2) Ilmu Hukum Program Pascasarjana UNUD, Denpasar, Bali. Alamat Jalan Drupadi XIII/ NO. 10 E Denpasar, e-mail: prabhata1ir@hotmail.com maupun wisata budaya. Wisata alam, misalnya meliputi 47 obyek wisata, seperti panorama di Kintamani, Pantai Kuta, Legian, Sanur, Tanah Lot, Nusa Panida, Nusa Dua, Karang Asem, Danau Batur, Danau Bedugul, Cagar Alam Sangieh, Taman Nasional Bali Barat, dan Taman Laut Pulau Menjangan.

Wisata budaya meliputi 83 obyek wisata, seperti misalnya wisata seni di Ubud, situs keramat Tanah Lot, upacara barong di Jimbaran dan berbagai tempat seni dan galeri yang sekarang banyak bermunculan di beberapa tempat diBali. Obyek wisata budaya 
ini sangat berkembang pesat, apalagi banyak karya seni yang dihasilkan oleh pelukis dan pematung dari Bali. Harga lukisan dan patung buatan Bali, harganya bisa mencapai puluhan hingga ratusan juta rupiah. Bahkan, ada beberapa pelukis asing yang sudah lama menetap di Bali, seperti Mario Blanco, Arie Smith, Rudolf Bonner dan sebagainya. Bali dengan citranya sebagai wisata Budaya sangat menarik minat bagi wisatawan yang akan berkunjung. Wisata budaya sangat penting untuk di pertahankan keberadaanya karen merupakan bagian penting dalan dunia pariwisata hal ini juga di ungkapkan dalam Report WTO yang berjudul Cultural Tourism and Local Communities :

"Cultural tourism is particular of the tourism sector, wich is not simple to define, since culture itself is a complex and manyfaceted concept. One common understanding of cultural tourism is when the visit tangiblle heritage sites represent the main componet of journey. Moved by esthetical, emotional, family and truly historical reasons, tourist have always travelled for the specific purpose of visiting the great monuments, sites and cultural landscape of the world"'

Begitupuladenganwisatasejarah, dapat dilihat berbagaipeninggalan sejarah beberapa kerajaan seperti Karangasem, Klungkung, dan Buleleng. Potensi obyek wisata di Bali yang telah menyumbang devisa negara dan pendapatan asli daerah Bali, sebenarnya masih potensial untuk dikembangkan lebih maju lagi. Kota Denpasar yang strategis dan

WTO, 2006, International Confrence on Cultural Tourism and Local Community, Calle Capitan Haya, Madrid Spain, hlm.47. memiliki fasilitas cukup baik dalam hal jasa perdagangan, serta memiliki bandar udara internasional, harus dapat dimanfaatkan untuk berbagai keperluan seperti pelayanan pariwisata dan perdagangan internasional.

Data wisatawan mancanegara yang berkunjung ke Bali pada 2012, menurut BPS, mencapai 1.230.316 orang. Pada 2013 jumlah wisatawan asing agak menurun, yakni hanya 1.187 .153 orang atau turun 3,51\% dibandingkan 2012. Sedangkan jumlah wisatawan domestik pada 2013 diperkirakan mencapai 300.000 orang. Para wisatawan itu berasal dari beberapa negara, seperti Amerika Serikat, Kanada, Jepang, Korea Selatan, Singapura, Malaysia, Australia, Inggris, Jerman, Perancis, Thailand, dan sebagainya. Jumlah hotel di seluruh Bali sampai 2013 ada sekitar 204 unit, dengan kapasitas kamar sebanyak 14.626 buah. Selain keindahan panoramanya, daya tarik pariwisata Bali antara lain juga dipengaruhi oleh kekhasan kesenian dan kebudayaannya, termasuk ritual agama Hindu yang dianut mayoritas orang Bali, serta keramahan masyarakat di Bali. $^{3}$

Survey World Economic Forum yang berkedudukan di Swiss, yang diberi nama Travel and Tourism Competitiveness Report (2013) menempatkan Indonesia di peringkat nomor 81 dunia, naik satu tingkat dari tahun sebelum. Tiga besar top-ranking pariwisata dunia adalah Swiss, Austria dan Jerman. Singapura berada pada peringkat 10, sementara Malaysia nomor 32, Thailand

Info Provinsi Bali, 2013, "Data Wisatawan yang Berkunjung ke Bali", diambil dari situs:http://www. disparda.baliprov.go.id, diakses pada hari Jumat tanggal 2 oktober 2013. 
nomor 39 dan Brunei pada nomor 69. Negaranegara Asean yang berada dibawah peringkat Indonesia adalah Filipina nomor 86, Vietnam nomor 89 dan Kamboja nomor 108. Kegiatan pariwisata tahun 2007 hingga tahun 2013 sungguh memberi peranan berarti terhadap keseluruhan kinerja perekonomian Indonesia. Tahun 2007 menunjukkan dampaknya berupa nilai produksi total Rp 362,10 triliun, yang berarti 4,62 \% dari total produksi nasional $\mathrm{Rp}$ 7.840,57 trilliun. Menghasilkan nilai tambah sektoral $\mathrm{Rp} 169,67$ triliun atau $4,29 \%$ dari PDB Indonesia yang bernilai Rp 3.957,40 trilliun. Mempekerjakan 5,22 juta orang sama dengan 5,22\% dari lapangan kerja nasional yang 99,93 juta orang. ${ }^{4}$

Dunia kepariwisataan menyangkut kegiatan wisatawan dari mulai kedatangan di pintu masuk (bandara, terminal, atau stasiun), di obyek wisata, di hotel, di restoran, di toko cindera mata dan sebagainya ${ }^{5}$. Selain itu pariwisata berhubungan erat dengan pengertian perjalanan wisata, yaitu sebagai suatu perubahan tempat tinggal sementara seseorang di luar tempat tinggalnya karena suatu alasan dan bukan untuk melakukan kegiatan yang menghasilkan upah. ${ }^{6}$ Kedatangan mereka ke Indonesia atau ke suatu kota itu salah satunya atas peran sebuah biro perjalanan sebagai pihak yang menjual program atau pihak yang punya tamu. Selanjumya kegiatan wisatawan selama dalam masa liburannya banyak

DPD HPI Bali, 2012, "Banyak Pemandu Liar di Bali", di ambil dari situs: http://www.hpibali.org/. diakses pada hari Minggu, tanggal 12 februari 2014.

5 Mauladi A.J, 2014, Kepariwisataan dan Perjalanan, Penerbit Rajawali Press, Jakarta, hlm.24.

6 Gamal Suwantoro, 2004, Dasar Dasar Pariwisata, Penerbit ANDI, Yogyakarta, hlm.3. berhubungan dengan seorang pramuwisata. Disinilah peran utama seorang pramuwisata, baik buruknya kesan wisatawan banyak ditentukan oleh peran seorang pramuwisata.

Pramuwisata atau juga bisa disebut pemandu wisata (guide) sangat dibutuhkan danberperan penting dalambisnis pariwisata. ${ }^{7}$ Dimana, para turis yang tengah berwisata tak cuma ingin menikmati pemandangan. Mereka juga ingin mengerti sejarah dan perkembangan lokasi yang dikunjunginya. Seorang pramuwisata profesional akan bisa membantu wisatawan untuk memenuhi kebutuhan dan keinginan wisatawan. Dengan pengalamannya seorang pramuwisata juga mampu untuk memberikan pelayanan, petunjuk, informasi dan hal-hal yang sangat dibutuhkan oleh seorang wisatawan. Dengan pengalamannya juga merupakan sumber informasi penting tentang diri wisatawan, menyangkut kebutuhan keinginan dan standar pelayanan wisatawan yang akan sangat bermanfaat untuk pengembangan kepariwisataan di daerah maupun nasional.

Pramuwisata (tour guide) adalah seseorang yang bertugas memberikam bimbingan, penerangan, petunjuk dan berbagai pelayanan kepada para wisatawan. ${ }^{8}$ Pemandu wisata atau disebut juga pramuwisata adalah orang atau badan usaha yang bergerak di bidang kepariwisataaan. Pramuwisata atau sering di sebut dengan tour guide dalam bahasa Inggris di Indonesia, secara nasional telah dibentuk

Bambang Udoyono, 2011, English For Tourism : Panduan Berfrofesi Dalam Dalam Dunia Pariwisata, Penerbit ANDI, Yogyakarta, hlm.48.

I Ketut Ardana, 2013, Menjadi Pramuwisata Profesinal, Tabur Kata Publishing, Denpasar, hlm.7. 
organisasi yang mewadahi profesi ini yaitu Himpunan Pramuwisata Indonesia atau HPI organisasi ini telah memiliki jaringan ke seluruh indonesia. Di beberapa daerah terbentuk sejumlah organisasi serupa yang bersifat lokal. Dalam Perda Nomer 5 Tahun 2008 Tentang Pramuwisata (selanjutnya di sebut Perda No. 5/2008), seseorang hendak menjadi pramuwisata di Indonesia disyaratkan memiliki lisensi yang dalam Perda No. 5/2008 tersebut disebutkan sebagai Kartu Tanda Pengenal Pramuwisata atau KTPP (selanjutanya dalam tesis ini di sebutkan KTPP) Pramuwisata yang diterbitkan oleh Gubernur melalui Dinas Pariwisata provinsi (pasal 4) dan juga dalam Peraturan Daerah Nomor 1 Tahun 2010 Tentang Usaha Jasa Pariwisata (senjutnya dalam tesis ini disebut dengan Perda No1/2009) menyatakan bahwa pengusaha Usaha Jasa Perjalanan Wisata (selanjutnya disebut dengan UJPW) wajib menggunakan pramuwisata yang memiliki sertifikat memiliki kartu tanda pengenal pramuwisata (Pasal 11). Berdasarkan fakta-fakta tersebut diatas, menunjukkan bahwa perkembangan pariwisata di Bali sangat berkembang pesat. Tidak menutup kemungkinan menimbulkan adanya Pramuwisata yang tidak berlisensi atau sering disebut dengan Guide Illegal.

Salah satu bukti nyata yang sempat menjadi pembicaraan hangat dimasyarakat, bahwa pekerja hotel sekarang ikut-ikutan menjadi pramuwisata. Meskipun sudah sesuai aturan jika orang yang boleh menjadi pramuwisata di Bali adalah orang lokal Bali sendiri, namun mereka yang secara sembunyi-sembunyi melakukan praktik guiding tanpa lisensi jelas-jelas merugikan pramuwisata yang berlisensi. Hal tersebut sempat dilaporkan kepadaDisparda setempat, namun hingga kini belum ada tindakan.

Untuk mendapatkan sebuah lisensi memang tidak mudah. Para guide harus mengikuti beberapa tahapan seperti diwajibkan mengikuti pelatihan pramuwisata dari Disparda Bali dan HPI Bali. Sementara, mereka yang tidak pernah mengikuti sertifikasi ikut berebut dengan pramuwisata berlisensi dilapangan, jika tidak segera ditangani dengan cepat, kemungkinan pramuwisataberlisensitidak akanmau mecari lisensi lagi. Keberadaan pramuwisata yang tidak mengantongi lisensi guiding berpotensi merusak citra Bali di mata wisatawan dan berakibat pada kunjungan wisata selanjutnya, karena dalam kenyataanya, mereka tidak menguasai budaya Bali, jika menjelaskan soal budaya kepada turis kemungkinan terjadi kesalahan.

Persyaratan untuk mendapatkan lisensi dari Disparda pemandu wisata wajib mengikuti seminar dan pendidikan selama 1 (satu) minggu atau minimal 110 jam untuk dapat menerima sertifikat yang secara langsung menjadi lisensi atau izin untuk pramuwisata dalam melaksanakan profesi sebagai pramuwista yang memiliki dedikasi dan profesinalisme dalam menjalankan pekerjaannya, memberi informasi yang valid dan bimbingan yang berkualitas kepada wisatawan yang berkunjung. Kebanyakan pramuwisata yang melakukan profesinya secara illegal atau tidak memiliki lisensi mungkin dikarenakan malasnya para pramuwisata tersebut mengurus lisensi ke Dinas Pariwisata yang dalam hal ini memiliki wewenang untuk mengeluarkan sertifikat 
sebagai syarat legalnya profesi pramuwisata dengan persetujuan dari Gubernur.

Dalam dunia kepariwisataan terutama dalam pelayanan jasa pariwisata yang di tawarkan kepada wisatan ternyata masih banyak terjadi penyimpangan, seperti yang sudah di paparkan diatas yaitu para pelaku profesi kepariwisataan yang disini kita sebut dengan pramuwisata ada yang menjalankan tugasnya sudah memiliki lisensi dari pemerintah ada juga yang masih nakal dengan melakukan profesi tanpa lisensi sesuai dengan ketentuan yang berlaku, namun dalam hal ini sudah sangat jelas melanggar apa yang menjadi keharusan seorang pramuwisata dalam menjalankan profesinya, kemudian pramuwisata yang mempunyai lisensi ada juga yang tidak sesuai dengan ketentuan yang sudah diatur dalam Perda No. 5/2008 jadi tidak tersertifikasi dan diragukan juga kualitasnya, karena pada dasarnya tidak mengikuti pendidikan atau pelatihan sebagai bekal dan tidak sesuai dengan kode etiknya sebagai pramuwisata yang baik sesuai dengan peraturan yang berlaku, hal ini tidak hanya menurunkan kualitas seorang pramuwisata namun juga dapat membuat lisensi sebagai pramuwisata di ragukan fungsinya sebagai tolak ukur kualitas seorang pramuwisata.

Berdasarkan praktek tersebut perlu diteliti sebab-sebab yang mengakibatkan pramuwisata tidak mentaati peraturan yang berlaku dan penegakan yang diperluan untuk mengekfektifkan pelaksanaan ketentuan sertifikasi dalam rangka pemeliharaan kualitas dari pramuwisata.

Bertitik tolak dari uraian yang telah dikemukakan diatas, maka penulis tertarik untuk mengangkat suatu tema yang akan penulis bahas dengan judul;

"PELAKSANAAN PERATURAN DAERAH PROVINSI BALI NO 5 TAHUN 2008 TENTANG PRAMUWISATA DI KABUPATEN BADUNG"

\subsection{Rumusan Masalah}

Berdasarkan uraian dari latar belakang diatas maka dapat dirumuskan pokok-pokok permasalahan sebagai berikut:

1. Apakah yang menjadi sebab ketentuan tentang lisensi dan sertifikasi seorang pramuwisata berdasarkan Peraturan Daerah Provinsi Bali No. 5 tahun 2008 tentang pramuwisata tidak dapat dilaksanakan?

2. Bagaimanakah bentuk pelaksanaan sanksi Peraturan Daerah Provinsi Bali No. 5 tahun 2008 tentang pramuwisata terhadap pramuwisata yang tidak memenuhi ketentuan serifikasi ?

\subsection{Tujuan Penelitian}

Menganalisa bagaimana pelaksanaan Perda No.5/2008 tentang Pramuwisata di Kabupaten badung, dan apa saja yang menjadi penghampat dalam pelaksanaanya begitu juga sanksi yang di berikan oleh pemerintah yang berwenang bagi yang melanggar ketentuan yang berlaku.

\section{Metode}

Jenis penelitian yang digunakan dalam penelitian ini adalah penelitian hukum empiris, suatu pendekatan terhadap masalah dengan cara mengkaji permasalahan yang muncul dalam kenyataan dilapangan dan selanjutnya dihubungkan dengan peraturan- 
peraturan hukum dan teori-teori hukum yang ada. Penelitian beranjak dari adanya kesenjangan antara das solen dengan das sein yaitu adanya kesenjangan antara peraturan-peraturan dengan realita atau dengan fakta hukum, dan adanya situasi ketidaktahuan yang dikaji untuk pemenuhan kepuasan akademik ${ }^{9}$, dengan demikian tidak hanya mempelajari fakta hukum tetapi juga bahan-bahan yang sifatnya normatif dalam rangka mengolah dan menganalisa data dari lapangan yang disajikan dalam pembahasan. Sifat penelitian ini adalah deskriptif analitis. Dikatakan deskriptif dikarenakan oleh penelitian ini memiliki tujuan untuk memperoleh gambaran secara rinci, sitematis, dan menyeluruh mengenai bagaimana peranan pemerintah dalam mengatasi pertumbuhan pramuwisata tanpa lisensi dan juga pelaksanaan Perda No. 5/2008 yang masih banyak ditemui penyimpangan dalam kegiatan kepariwisataan, Bersifat analitis karena dengan menggunakan cara menganalisa data yang di peroleh oleh perundang-undangan yang berlaku, dari pendapat para ahli, dan teori-teoriilmu hukum yang berkaitan dengan peranan pemerintah daerah dalam mengatasi pertumbuhan pramuwisata tanpa lisensi dalam kegiatan kepariwisataan. Bahan Hukum Primer, yaitu data yang diperoleh langsung dari sumber pertama ${ }^{10}$. Data primer dalam penulisan tesis ini bersumber dari penelitian dilapangan

Bahder Johan Nasution, 2008, Metode Penelitian Dalam Hukum, Penerbit Mandar Maju, Bandung, hlm.125.

10 Amiruddin dan H. Zainal Asikin, 2003, Pengantar Metode Penelitian Hukum, Rajawali Pers, Jakarta, hlm.30. yang terkait dengan permasalahan yang akan .Bahan Hukum sekunder merupakan suatu data yang bersumber dari penelitian kepustakaan. Sumber data sekunder di dalam penelitian ini di ambil dari dokumendokumen yang berbentuk bahan-bahan hukum. Bahan Hukum tersier, yakni bahan yang memberikan petunjuk maupuan penjelasan terhadap bahan hukum primer dan sekunder, seperti kamus, ensiklopedia, indeks komulatif dan sebagainya.

\section{Hasil dan Pembahasan}

\subsection{Penyebab Tidak Terlaksananya Perda No.5 tahun 2008 Tentang Pramuwisata di Kabupaten Badung.}

Ada dua faktor yang memyebabkan tidak terlaksanany dengan baik Perda No.5/2008 di Kabupaten Badung , yang pertamaadalahFaktorhukum:Kebijaksanaan pembangunan kepariwisataan di Indonesia tercermin dalam Undang-Undang Nomor 10 Tahun 2009 tentang Kepariwisataan banyak mengadopsi nilai-nilai yang sarat akan pembangunan yang berwawasan lingkungan dan penghargaan terhadap masyarakat hukum adat yang masih memanfaatkan kearifan-kearifan lokal dalam konteks kepariwisataan. Bentuk kearifan lokal yang di tuangkan dalam bentuk peraturan daerah adalah Perda No 5/2008 dalam perda tersebut telah diatur juga bagaimana dan apa yang harus di lakukan seseorang yang berprofesi sebagai pramuwisata, namun dalam pelaksanaan profesinya Pramuwisata sebagai pelaku kegiatan kepariwisataan tidak serta merta mentaati peraturan yang sudah di berlakukan oleh pemerintah, masih banyak 
pramuwisata yang melanggar ketentuan dari peraturan khususnya peraturan daerahtentang pramuwisata itu sendiri, banyak faktor yang menjadi penyebab perilaku menyimpang dari dari pramuwisata, salah satunya adalah faktor hukum. Dari hasil wawancara dengan ketua HPI Bali Bapak Made Sukadana yang dilakukan di kantornya di jalan tunjung sekar no 5 Denpasar Bali beliau menyatakan Undang-Undang No. 10 Tahun 2009 tentang Kepariwisataan membawa konsekuensi tidak menguntungkan bagi profesi Pramuwisata, karena tanpa adanya visi yang sama tentang pengembangan kepariwisataan secara umum termasuk pramuwisata. Menurunnya kualitas pelayanan pemanduan wisata oleh sebab pola recruitment yang tidak jelas dan pendidikan yang dipersingkat, terselenggara hanya selama 3 hari. Standard minimal diklat pramuwisata 110 jam tidak pernah terpenuhi dalam pelaksanaanya, meski hal ini bisa merujuk Standar Kompetensi Kerja Nasional Indonesia, masih muncul keluhan wisatawan bahwa pramuwisata kurang menguasai budaya lokal. dalam UndangUdang no 10 tahun 2009 tentang Pariwisata sebagai dasar di bentuknya peraturan daerah Provinsi Bali no 5 tahun 2008 tentang Pramuwisata tidak di sebutkan secara jelas pengaturan tentang profesi pramuwisata itu sendiri, dalamperaturanperundangUndangan tersebut hanya di katakan dalam Pasal 26 huruf $\mathrm{h}$ "meningkatkan kompetensi tenaga kerja melalui pelatihan dan pendidikan" tidak jelas di katakan seorang pramuwisata harus memiliki lisensi dan juga mengenai standar untuk pelatihan sebagai dasra untuk menjalankan profesi kepariwisatan ini hal yang membuat masyarakat meremehkan dan acuh tak acuh atau tidak perduli pada aturan yang berlaku, oleh karena tidak adanya kejelasan dari peraturan perundangundangan sebagai dasar terbentuknya peraturan daerah. HPI tidak dapat menjawab tantangan profesionalitas, yaitu regenerasi pramuwisata, kualitas kompetensi, apatisme anggota, standart etik pemanduan dan kebutuhan struktur kelembagaan di tingkat operasional. Secara internal apakah HPI telah menjalankan Garis-garis Besar Haluan Organisasi, termasuk fakta bahwa syarat2 keanggotaan diisyaratkan Anggaran Rumah Tangga menjadi penghalang hubungan struktural sebuah organisasi profesi yang modern. Multi peran Pramuwisata sebagai eksekutor layanan wisata, duta nasional, sosok penghubung destinasi, juru penerang fakta masyarakat plural 'bhinneka' dengan satu idealita das Sollen Nusantara yang tunggal ika, namun bermasalah pada pemberdayaan diri dan keberpihakan pemerintah serta stakeholder pada profesi ini. Multi peran itu amat mulia ditinggikan, namun nilai profesi pramuwisata tak lebih baik dari Tukang Bangunan. Bicaralah pada Anggota HPI di pelosok negeri, bagaimana HPI dan Pemerintah era Otonomi Daerah tak mampu menaungi mereka, mulai soal pendidikan pramuwisata, pola kesejahteraan atau pembinaan yang mereka peroleh tanpa jaminan keselamatan kerja. Sehingga hal inilah yang membuat penurunan kualitas pramuwisata.

Yang kedua merupakan faktor non hukum : 
Seperti yang sudah di bahas dalam sub bab sebelumnya mengenai faktor-faktor apa sajakah yang menghambat penegakan hukum dengan kata lain menghambat pelaksanaan perda tersebut ada banyak faktor lain di lapangan yang ternyata juga membuat terhambatnya pelaksanaan Peraturan Daerah Provinsi Bali no 5 Tahun 2008 Tentang pramuwisata tidak hanya di bidang hukum saja namun dari sisi lain juga banyak menjadi penghambat pelaksanaan perda yang menjadi bagian dari fator penghambat dari pelaksanaan perda adalah :

\section{Faktor Ekonomi}

Ekonomi menjadi salah satu fator yang sangat berpengaruh menjadi penghambat pelaksanaan perda tentenga pramuwisata, mengapa demikian? semua masyarakat dalam berbagai lapisan membutuhkan pekerjaan untuk menghasilkan uang demi memeuni kebutuhan hidupnya, dimana lingkungan kitamerupakan daerah yang memiliki kegiatan ke pariwisataan yang sangat tinggi, hampir 60\% masyarakat di Bali memiliki profesi di bidang pariwisata salah satunya pekerjaan yang mudah di lakukan adalah menjadi pramuwisata, dengan memiliki pengetahuan tentang pariwisata di Bali dan juga bisa berbahasa Asing seseorang bisa melakukan pekerjaan ini dengan mudah, karna banyak wisatawan yang tidak mengerti bahkan mungkin tidak mengetahui bahwa pramuwisataitu sendiri pun harus memeiliki izin untuk menjalankan profesi, banyak pramuwisata yang tidak memiliki izin atau ilegal menawarkan harga jauh di bawah ratarata untuk mendapatkan wisatawan, sehingga hal inilah yang membuat banyak pramuwisata tanpa izin masih mbisa beroperasi dan malah semakin menjamur. Tidak hanya pramuwisata yang nakal namun juga Kepala Dinas Pariwisata Daerah (Disparda) Bali, berdasarkan hasil wawan cara pada tanggal 21 Desember 2014 di kantor Dinas kepariwisataan provinsi Bali, Anak Agung Gede Yuniartha Putra mengatakan, akan segera memberikan surat peringatan (SP) kepada biro perjalanan wisata (BPW) yang mempekerjakan pramuwisata atau guide ilegal dan dinas pariwisata pun akan segera menerbitkan SP (Surat Peringatan) kepada BPW menggunakan pramuwisata ilegal, langkah itu sebagai upaya menjaga citra Bali dalam memberikan pelayanan terbaik kepada wisatawan, beliau mengatakan, pihaknya kini sedang melakukan pengecekan dan razia pramuwisata, karena ditengarai masih banyak BPW yang mempekerjakan pemandu wisata tanpa memiliki surat izin, dan juga Dinas Pramuwisata akan segera menerbitkan SP kepada BPW yang nakal. Karena dalam Perda No 10 tahun 2009 Tentang Usaha Perjalan Pariwisata, sudah ada aturan jelas mengenai pemandu wisata, dalam perda tersebut dinyatakan semua BPW harus menggunakan pramuwisata yang berlisensi atau berizin. Jika ada BPW yang mempekerjakan guide ilegal berarti BPW tersebut melanggar kebijakan dan akan diberikan SP hingga beberapa kali sebelum diberikan tindakan tegas berupa pencabutan izinnya.

\section{Faktor Pendidikan}

Jumlah wisatawan yang terus meningkat tiap tahunnya membuat kebutuhan akan jumlah pramuwisata juga sangat besar namun dalam pemenuhan kuota prramuwisata masih banyak kendala yang 
harus di hadapi Dalam Peraturan Daerah no 5 tahun 2008 tentang pramuwisata bagian kesatu tetang sertifikasi pramuwisata pasal 5 ayat (1) dan (2) huruf a, telah di sebutkan salah satu syarat untuk mendapatkan izin atau serifikat pramuwisata adalah memiliki pendidikan mimimal Diploma 3 (D3) atau yang sederajat, namum dalam kenyataanya di masyarakat masih banyak masyarakat kita khusunya di bali belum mampu untu melanjutkan pendidikannya ke jenjang yang lebih tinggi, namun karena lingkungan yang mengajarkanmerekamenjadimahirberbahasa asing, hal ini menjadi modal utama mreka untuk masuk ke profesi di dunia pariwisata. Bagi mereka dengan memilki kemampuan berbahasa asing dan pengetahuan seadanya tentang dunia kepariwisataan di Bali sudah menjadi modal cukup untuk emnjalankan profesi, pendidikan adalah hal yang tidak menjadi halangan untuk mendapatkan pekerjaan. Skill atau kempampuan adalah hal yang harus paling di utamakan untuk melakukan sebuah pekerjaan. Dengan perkembangan pariwisata yang sangat pesat seperti sekarang ini membuat masyarakat sendiri harus bida melihat peluang dalam mencari pekerjaan salah satunya yang paling mudah adalah menjadi pramuwisata tanpa memerlukan modal untuk membuka usaha mereka dapat menghasilkan uang. Hal inilah yang mendorong banyak masyarakat melakukan profesi pramuwistaa namun tidak sesuai dengan Peraturann yang berlaku

\section{Waktu perekrutan pramuwisata}

Pelaksanaan perekrutan pramuwisata yang tidak di laksanakan terus menerus membuatkesempatanbagicalon pramuwisata tidak memungkinkan untuk mendapatkan izin atau sertifak pramuwisata dengan segera membuat beberapa pramuwisata nekat menjalankan profesinya tanpa mengantongi izin, perekrutan pramuwista memang dilakukan dengan jangka waktu tertentu tidak reguler dilakukan tiap bulan ataupun tahun namun dilaksanakan sesuai dengan laporan dari DPD HPI jika mengalami kekurangan pramuwisata. Jika di lihat dari perkembangan pariwista di masa sekarang tentunya sangat banyak di perlukan jasa pramuwista membludaknya wisatawan yang datang memungkinkan di butuhkannya lebih banyak pramuwisata, namun kurangnya informasi dari para pelaku jasa praiwisata lain seperti agen wisata dan hotel yang menaungi para pramuwisata mengakibatkan informasi kebutuhan terhadap jasa pramuwisata menjadi terhambat ini mengakibatkan tidak adanya kecocokan data pramuwisata yang di butuhkan dan jumlah pramuwisata yang sudah melakukan profesi dengan tidak atau sudah mengantongi lisensi, banyak agen wisata atau hotel lebih suka mempekerjakan pramuwisata tanpa lisensi atau freelance untuk mendapatkan tenaga kerja dengan harga yang lebih murah.

\section{Syarat Syarat yang Ada dalam Perda No 5 tahun 2008 tentang Pramuwisata}

Banyak syarat yang sudah ditentukan dalam perda no 5 tahunn 2008 tentang pramuwisata untuk menjadi seorang pramuwisata yang bersertifikasi, namun jika di telaah banyak syarat yang sepertinya susah untuk di penuhi oleh para calon pramuwisata, salah satunya hal yang menjadi penyebab 
yang cukup signifikan untuk pelanggaran yang di lakukan oleh pramuwisata adalah seperti yang di sebutkan di pasal 5 ayat (2) huruf a nomor 2, di sebutkan bahwa :

"bertempat tinggal di kabupaten atau kota paling singkat 2 (dua) tahun yang di buktikan dengan kepemilikan kartu tanda penduduk "

Dengan adanya ketentuan seperti apa yang tertulis dalam Perda banyak masyarakat pendatangyanginginmemeperoleh pekerjaan di bidang pariwisata khusunya pramuwisata di daerah Bali dengan melihat peluang yang lebih besar denga kondisi pariwisata yang baik membuat banyak masyarakat pendatang nekat untuk tetap mengadu nasib dengan bekerja sebagai pramuwisata dengan tanpa mengantongi lisensi. Banyak masyarakat melanggar peraturan karena terdesak keadaan yang harus memiliki pekerjaan segera.

\section{1 pelaksanaan sanksi Peraturan}

Daerah Provinsi Bali No. 5 tahun 2008 tentang pramuwisata terhadap pramuwisata yang tidak memenuhi

\section{ketentuan serifikasi}

\section{Sanksi Administrasi}

Sanksi adminidtrasi di berikan kepada pramuwisata melalui Dinas pariwisata yang rutin melakukan razia atau sweeping ke tempat-tempat objek wisata yang ramai di kunjungi wisatawan untuk menjaring pramuwista yang tidak memiliki izin maupun pramuwisata yang memilkii izin tapi masih melanggar beberapa peraturan dalam Perda No.5/2008. Dinas pariwisata rajin melakukan razia atau sweeping di 33 objek wisata yang tersebar di seluruh Kabupaten Badung. Namun terkendala dengan anggaran dana yang terbatas membuat pelaksanaan razia dan sweeping maupun pengawasan menjadi terhambat, dengan adanya banyak objek wisata yang makin padat di kunjungi oleh wisatawan mengharuskan dinas pariwisata menyiapkan lebih banyak tenaga khusus di setiap objek wisata untuk mengawasi perkembangan kegiatan kepariwisataan. Menurut hasil wawancara yang dilakukan kepada kepala dinas kepariwisataan provinsi bali pada 24 desember 2014 Bapak Anak Agung Gede Yuniartha Putra, SH.MH, beliau menyatakan bahwa jika kalangan pelaksana pariwisata meminta disparda Bali menempatkan satu penjaga di setiap objek wisata untuk mengawasi pramuwisata yang tidak berslisensi maupun yang menjalankan profesi tidak sesuai dengan aturan yang berlaku, hal itu di rasa juga oleh bapak Ketut Suastika sulit terlaksana oleh karena untuk pengendalian terhadap pramuwisata hanya dilaksanakan oleh dinas pariwisata provinsi Bali saja. Sementara itu untuk menempatkan tenaga penjaga khusus di masing-masing objek wisata di butuhkan dana yang besar. Sementara itu, Disparda Bali masih menghadapi kendala dana sehingga upaya untuk menempatkan tenaga penjaga objek wisata untuk mengawasi kinerja dan jalannya kegiatan pariwisata terutama untuk mengurangi angka pelanggaran yang di lakukan oleh pramuwisata masih sulit terwujud. Namun dinas pariwisata masih tetap berupaya semaksimal mungkin untuk dapat menegakan peraturan dan mengurangi angka pelanggaran, pada tahap awal disparda Bali mengupayakan untuk membuat papan peringatan bagi wisatawan 
yang ingin memasuki daerah objek wisata di Bali, papan peringatan itu akan di tempatkan dibeberapa tempat di objek wisata, untuk memastikan dan memperingatkan kepada wisatawan apakah sudah mmenggunakan jasa pramuwisata yang sudah memilki lisensi. Meski belum bisa menyediakan petugas penjaga pramuwisata tanpa lisensi dan menjalankan profesi tidak sesuai dengan peraturan yang berlaku, disparda Bali akan tetap melakukanan razia atau sweeping rutin sebagai upaya untuk menjaring para pramuwisata nakal tersebut. Tim sweeping dari disparda Bali akan tetap melakukan sweeping secara rutin dan berkelanjutan guna menjaga ke stabilan kegiatan pariwisata dan mengurangi pelanggaran yang di lakukan oleh para pramuwisata juga mengurangi pertumbuhan pramuwisata liar yang sudah semakin meresahkan belakangan ini.

\section{Penjatuhan Sanksi}

Terkait dengan pelanggaran yang dilakukan oleh pramuwisata yang tidak sesuai dengan peraturan yang berlaku, akan di kenakan sanksi-sanksi sesuai dengan peraturan yang berlaku. hukuman kurungan atau pidana akan di kenakan pada pramuwisat yang kedapatkan melakukan pelanggaran lebih dari 3 (tiga) kali dan sudah pernah di kenakan snksi administrasi. Jika pelanggaran yang dilakukan oleh pramuwisata tersebut lebih dari 3 (tiga) kali pada saat melakukan pelanggran dan tertangkap oleh tim sweeping dinas pariwisata maka kasus tersebut akan langsung di ajukan oleh Dinas Pariwisata ke Dinas Satuan Polisi Pamong Praja atau satpol PP yang dalam hal ini berfungsi sebgai penyidik bagi kasus-kasus tindak pidana (pelanggaran) dalam bidang kepariwisataan yang di ajukan oleh Dinas Pariwisata, satpol PP berhak melakukan pemanggilan terhadap si pelaku pelanggaran dan melakukan penyidikan sehingga dapat memutuskan sanksi apa yang akan di jatuhkan, apakah berbentuk peringatan kembali, denda atau pencabutan lisensi bagi pramuwisata yang melakukan pelanggaran. Dalam Perda No. 5/2008 telah diatur mengenai ketentuan penyidikan yanng dilakukan oleh pejabat penyidik kepolisian negara Republik Indonesia yang bertugas menyidik tindak pidana, penyidikan yang sebagaimana diatur dalam Peratutan Daerah ini dapat juga di lakukan penyidik Pegawai negeri Sipil di lingkungan Pemerintah Provinsi Bali

\section{Penutup}

\subsection{Simpulan}

1. Yangmenjadipenghambatpelaksanaan Perda No. 5/2008 ada 2 (dua) yaitu , Faktor hukum dan faktor Non Hukum, Untuk faktor hukum adalah : tidak adanya pengaturan jelas dalam perda mengenai standar waktu untuk pendidikan pramuwisata dan waktu untuk rekruitmen bagi pramuwisata, dan faktor non hukum nya : pendidikan , ekonomi, waktu rekruitmen dan juga beberapa syarat dalam perda yang tidak bisa di penuhi oleh calon pramuwista.

2. Ada 2(dua) jenis sanksi yang di berikan bagi pramuwisata yang menjalankan profesi tidk sesuai dengan peraturan yang berlaku : yang pertama sanksi admnisitrasi dan penjatuhan sanksi pidana. 


\subsection{Saran}

1. Perlu adanya pembaharuan dalam Perda No.5/2008 tentang pramuwisata mengenai waktu standar untuk pelatihan atau pendidikan pramuwisata daan juga di buat mengenai waktu reckruitmen bagi pramuwisata.

2. Perlu adanya tindakan yang lebih tegas lagi bagi pramuwista yang melakukan pelanggran tehadap peraturan yang berlaku.

\section{Daftar Pustaka :}

\section{Buku :}

WTO, 2006, International Confrence on Cultural Tourism and Local Community, Calle Capitan Haya, Madrid Spain

Mauladi A.J, 2014, Kepariwisataan dan Perjalanan, Penerbit Rajawali Press, Jakarta

Gamal Suwantoro, 2004, Dasar Dasar Pariwisata, Penerbit ANDI, Yogyakarta

Bambang Udoyono, 2011, English For Tourism : Panduan Berfrofesi Dalam Dalam Dunia Pariwisata, Penerbit ANDI, Yogyakarta

Ketut Ardana, 2013, Menjadi Pramuwisata Profesinal, Tabur Kata Publishing, Denpasar

Bahder Johan Nasution, 2008, Metode Penelitian Dalam Hukum, Penerbit Mandar Maju, Bandung

Amiruddin dan H. Zainal Asikin, 2003, Pengantar Metode Penelitian Hukum, Rajawali Pers, Jakarta

\section{Internet :}

Info Provinsi Bali ,2013, "Data Wisatawan yang Berkunjung ke Bali”, diambil dari situs: http://www.disparda.baliprov. go.id/, diakses pada hari Jumat tanggal 2 oktober 2013.

DPD HPI Bali, 2012, "Banyak Pemandu Liar di Bali”, di ambil dari situs: http:// www.hpibali.org/. diakses pada hari Minggu, tanggal 12 februari 2014

\section{Peraturan Perundang-Undangan :}

Undang-Undang No. 10 tahun 2009 Tentang Kepariwistaan

Peraturan Darah Provinsi Bali No. 1 tahun 2010 tentang Biro Perjalan Wisata

Peraturan Daerah Provinsi Bali No. 5 Tahun 2008 Tentang Pramuwista 